\title{
The effect of Alfalfa (Medicago sativa L.) on different basal feeds for hybrid duck performance
}

\author{
Salnan Irba Novaela Samur, Bambang Suwignyo*, and Edi Suryanto \\ Faculty of Animal Science, Universitas Gadjah Mada, Jl. Fauna No. 3, Bulaksumur, Yogyakarta, 55281, Indonesia
}

\begin{abstract}
The aimed of this research was to determine effect of Supplementation of Alfalfa (Medicago sativa L.) on different basal feeds for hybrid duck performance. This research was conducted by in vivo method with 120 MA (Mojosari x Alabio) of hybrid ducks type. The method was being used in this research include 4 treatments and 6 repetitions with 5 ducks each repetition. The treatment consisteds of $\mathrm{P} 1=$ Commercial feed $100 \%$, P2 $=$ Alternative feed $100 \%$, P3 = Commercial Feed $90 \%+$ supplementation of fresh alfalfa $10 \%$ and $\mathrm{P} 4=$ Alternative feed $90 \%+$ supplementation of fresh alfalfa $10 \%$. Feed and water was offered Ad libitum. The Observed variables were feed consumption, body weight gain and feed conversion ratio (FCR). The data was analyzed by the Program of Statistical Package for Social Science (SPSS) version 22. Duncan's multiple range test (DMRT) analyzed was implanted for significant differences data. The results showed that $10 \%$ alfalfa supplementation in commercial feeds and alternative feeds have significant lower/higher $(\mathrm{P}<0.05)$ value of feed consumption, weight gain and FCR value. Based on these results it can be concluded that commercial feed without alfalfa supplementation was the most optimal treatment of other treatment feeds for hybrid duck performance.
\end{abstract}

Keywords: Alfalfa, commercial feed, alternative feed, performance, hybrid duck

\section{Introduction}

Meat consumption in Indonesia is generally sourced from ruminant animals such as cows, goats and sheep and poultry such as chickens, thugs and ducks. Duckling as one source of animal protein is indeed worth considering. The advantage of animal raising is that the duck body is more resistant to disease so that the maintenance is easy and contains less risk [1]. Besides, duck meat has a savory taste compared to chicken [2].

Alfalfa is a good source of protein and rich in mineral and vitamin content [3]. Specifically, alfalfa contains vitamins A, D, E, K, C, B1, B2, B6, B16, niacin, pantothenic acid, inositol, biotin, and folic acid. Alfalfa also contains several minerals, such as phosphorus, calcium, potassium, sodium, chlorine, sulfur, magnesium, copper, manganese, iron, cobalt, boron and molybdenum. Alfalfa plants also contain amino acids that are rich in carotenoids, xanthophils which give a yellow color to the carcass [4,5]. Furthermore, alfalfa has $17.5 \%$ of crude protein content, $24.1 \%$ of crude fiber, and $1200 \mathrm{kcal} \mathrm{kg}^{-1}$ of energy [6]. The average content of dry matter, organic matter, ether extract and crude protein in fresh alfalfa according to Suwignyo et. al. [21] on land without fertilizer and dolomit addition was $18.55 \%, 87.95 \%$, $8.57 \%$ and $28.54 \%$.

Alfalfa has flavonoid content that can improve growth performance when supplemented as broiler chicken feed [7]. The content of isoflavones in alfalfa can increase the average growth of body weight and stomach weight of mice. The increase in growth due to flavonoid content stimulates the combination of growth hormone and liver growth hormone receptors so that the increased insulin concentration causes an increase in growth in animals [8]. The content of crude fiber in alfalfa can increase feed consumption. The increase of feed consumption is caused by the crude fiber that affects the fast feed rate [9].

Comparison of alfalfa supplementation in different forms of basal feed (commercial and alternative feed) has not been studied by previous studies, therefore this study was conducted with the aim to determine the effect of alfalfa supplementation in different forms of basal feed on hybrid ducks on the performance of hybrid duck production.

\section{Materials and methods}

Male MA hybrid ducks (Mojosari x Alabio). The equipment used is pen including a battery cage with a size of $90 \mathrm{~cm} \times 90 \mathrm{~cm} \times 60 \mathrm{~cm}$, a Medivac Ai brand feed container with a capacity of $5 \mathrm{~kg}$, a Medivac Ai brand drinking container with a capacity of $2 \mathrm{~L}$, a wooden base litter and a Camry digital scale with a maximum capacity $5 \mathrm{~kg}$ for weighing feed. The materials used in this research was fresh alfalfa leaves, commercial feed BR-1 from PT. Japfa Comfeed ${ }^{\circledR}, 70 \%$ alcohol, and medics to wash feed and drink containers. The study design was a complete randomized design consisting of 4 treatments, 6 replications and each repetition had 5 ducks. The treatment of feed given is $\mathrm{P} 1=$ commercial

\footnotetext{
* Corresponding author: bsuwignyo@ugm.ac.id
} 
feed $100 \%, \mathrm{P} 2$ = alternative feed, $\mathrm{P} 3=$ commercial feed $90 \%+$ fresh alfafa $10 \%$ and $\mathrm{P} 4=$ alternative feed + fresh alfafa $10 \%$.

Ducks are maintained for $40 \mathrm{~d}$. Feeding and drinking during maintenance was done offered ad libitum. Each basal feed that was supplemented with 10 $\%$ fresh alfalfa. Ducks body was weekly checked.

Table 1. Composition and nutrient content of the ration

\begin{tabular}{lllll}
\hline \hline \multirow{2}{*}{$\begin{array}{c}\text { Nutrient } \\
\text { Ration } \\
\text { (\% BK) }\end{array}$} & \multicolumn{4}{c}{ Treatment* } \\
\cline { 2 - 5 } \multicolumn{1}{c}{ P1 } & P2 & P3 & P4 \\
\hline ME (Kcal/kg) & 3000,00 & 2928,00 & 2910,00 & 2853,00 \\
Crude protein & 21,90 & 19,17 & 21,79 & 18,94 \\
Crude Fat & 5,40 & 5,90 & 5,62 & 6,53 \\
Crude Fiber & 5,40 & 3,54 & 6,71 & 6,04 \\
Ca & 1,00 & 0,73 & 1,03 & 1,12 \\
P available & 0,21 & 0,52 & 0,95 & 0,69 \\
Lysine & 1,07 & 1,41 & 1,19 & 2,11 \\
Methionine & 0,49 & 0,58 & 1,02 & 0,87 \\
\hline
\end{tabular}

* P1: commercial feed; P2: alternative feed, P3: commercial feed $+10 \%$ alfalfa; $\mathrm{P} 4$ : alternative feed $+10 \%$ alfalfa

\subsection{Feed consumption}

The feed offered and the rested were weighed and recorded to find out the amount of feed consumption. According Nuningtyas (2014) Feed consumption can be calculated by reducing the feed offered with the remaining feed as follows:

Feed consumption $=$ Feed offered - leftover feed (1)

\subsection{Body weight growth}

Weighing was done at the beginning and end of the maintenance phase. According Nuningtyas (2014) Body weight growth is the difference between initial weight and final weight during maintenance, which can be seen in the following Equation:

$$
\text { Growth weight }=\frac{\text { Final weight }- \text { Initial weight }}{\text { Time (day) }}
$$

\subsection{Feed conversion ratio (FCR)}

The FCR value can be calculated by dividing the amount of feed consumed in a given week by the growth of body weight in that week (Nuningtyas, 2014).

$$
\mathrm{FCR}=\frac{\text { Feed consumed }(\mathrm{g} / \mathrm{duck})}{\text { weight gain }(\mathrm{g} / \text { week })}
$$

\subsection{Statistical analysis}

The data of the research were analyzed using Complete Randomized Design (CRD) then the result were analyzed with the Statistical Package for Social Science version 22 (SPSS Gmbh, Munich, Germany). Duncan's multiple range test (DMRT) Analyzed was implemented for significant differences data [10].

\section{Results and discussion}

The effect of alfalfa supplementation on commercial feeds and alternative feeds for feed consumption (FI), body weight gain (PBB), and the value of Feed Conversion Ratio (FCR) can be seen in Table 2.

Table 2. Average of feed consumption, body weight gain, and feed conversion ratio values

\begin{tabular}{lcccc}
\hline \hline \multirow{2}{*}{ Parameter } & \multicolumn{4}{c}{ Treatment } \\
\cline { 2 - 5 } & P1 & P2 & P3 & P4 \\
\hline FI & 3143.84 & 2927.47 & 3865.77 & 2847.57 \\
(g/ tail) & $\pm 74.18^{\mathrm{b}}$ & \pm & $\pm 70.07^{\mathrm{a}}$ & $\pm 75.97^{\mathrm{c}}$ \\
& & $138.46^{\mathrm{ab}}$ & & \\
$\mathrm{BW}$ & 1065.56 & $886.92 \pm$ & 1056.42 & $708.12 \pm$ \\
(g/ tail) & $\pm 7,75^{\mathrm{a}}$ & $3,97^{\mathrm{b}}$ & $\pm 9,16^{\mathrm{a}}$ & $2.46^{\mathrm{c}}$ \\
FCR & $2.96 \pm$ & $3.30 \pm$ & $3.65 \pm$ & $4.02 \pm$ \\
& $0.08^{\mathrm{d}}$ & $0.15^{\mathrm{c}}$ & $0.04^{\mathrm{b}}$ & $0.04^{\mathrm{a}}$ \\
\hline
\end{tabular}

Note: different superscript abcds show significantly different $(\mathrm{P}<0.05)$

FI $=$ Feed Intake / Feed Consumption

BW = Body Weight Gain

$\mathrm{FCR}=$ Feed Conversion Ratio

P1 $=100 \%$ Commercial Fedicagoeedm

P2 $=100 \%$ Alternative Feed

P3 = Commercial Feed $90 \%+$ fresh alfalfa $10 \%$

P4 = Alternative Feed $90 \%$ + fresh alfala $10 \%$

\subsection{Feed consumption}

Based on the data in Table 2, it is seen that supplementation of $10 \%$ fresh alfalfa in commercial feed and alternative feed show a significant effect $(\mathrm{P}<0.05)$ on the consumption of hybrid duck feeds. 10 $\%$ alfalfa supplementation in commercial feed (P3) showed the highest feed consumption when compared with all treatments. However, alfalfa $1 \quad 0 \%$ supplementation on alternative feed (P4) showed the lowest value of feed consumption when compared to all treatments.

The highest value of consumption is found in the P3 treatment while in P4 the was the lowest among the others. P3 treatment showed the highest value of consumption can be caused by crude fiber feed which is sourced from the addition of fresh alfalfa. Giving alfalfa as feed could increase the value of consumption in birds [11]. Consumption could be increased because there is a value of crude fiber that affects the fast feed rate [9]. This rapid rate is also due to increased drinking water consumption due to bulky crude fiber [12].

Low consumption in treatment $\mathrm{P} 4$ could be caused by the form of feed offered. The treatment of P1 and P3 were using crumble feed, whereas for P4 and P2 were a mash form. Feeding the form of mash feed causes duck difficulty in swallowing so it requires more water to digest [15]. The low consumption of feed was also caused by the behavior of ducks that drink immediately after eating. Leftover feed that was still in the beak would fall and dissolve into the drinking water. 


\subsection{Body Weight Gain}

Based on the data in Table 2, it was seen that $10 \%$ supplemented of fresh alfalfa in commercial feed and alternative feed showed a significant effect $(\mathrm{P}<0.05)$ on the weight gain of hybrid ducks. Without alfalfa supplementation in commercial feed (P1) and $10 \%$ of alfalfa supplementation in commercial feed (P3) showed the highest level of body weight gain when compared to alternative feed. This could be caused by the type of feed consumed by livestock. In treatment P1 and P3, the type of feed offered were crumble, whereas in treatment P2 and P4, the type of feed offered were mash. It was also seen that feed consumption in commercial feed was greater when compared to alternative feed (Table 2). So that it proved that crumble-shaped feed was consumed more by ducks than mash-shaped feed, so that the growth rate of ducks fed mash-shaped feed tends to be lower. Mash form feeding was gives the lowest level of body weight because ducks have difficulty in swallowing feed so that the frequency of drinking was higher [15].

Weight gain also could be influenced by the content of feed fiber. In the P1 treatment, there was no alfalfa supplementation so that the crude fiber content in the feed was lower, so it was seen that the value of body weight gain in the $\mathrm{P} 1$ was greater when compared to the P3 treatment, although it did not show any significant difference. The same thing happened to alternative feeds in P2 treatment, body weight gain of hybrid ducks was higher compared to P4 treatment. High crude fiber in could affect the feed rate in the digestive tract and also affect the rate of absorption of nutrients so that it affects the body weight gain [9].

\subsection{Feed Conversion Ratio (FCR)}

Based on the data in Table 2, it could be seen that fresh alfalfa supplementation of $10 \%$ in commercial feed and alternative feed showed a significant effect $(\mathrm{P}<0.05)$ on the FCR level of hybrid duck. The $10 \%$ alfalfa supplementation in commercial feed (P3) showed a greater FCR level compared to commercial feed without alfalfa supplementation (P1). In alternative feed, $10 \%$ alfalfa supplementation (P4) also showed a greater FCR value compared to alternative feed without alfalfa supplementation (P2). The result of FCR level from Suwignyo et. al. [20] research in commercial feed without alfalfa supplementation at the 4 th week was 3.33 it was higher than the results of this research on P1 treatment (Table 2). Whereas the treatment of commercial feed with $6 \%$ alfalfa supplementation at the 4 th week showed FCR of 3.41. It was lower than commercial feed treatment with $10 \%$ alfalfa supplementation (P3) in this study (Table 2).

The lowest FCR level in all treatments was at treatment P1 of 2.90, while the greatest FCR level was at treatment of 4.02. The FCR value obtained in this study was supported by research [16] that used alfalfa with an additional level of $3 \%$ has an FCR value of 3.08 , additional level of alfalfa $6 \%$ has an FCR value of 3.07 , an additional level of $9 \%$ alfalfa has an FCR value of 3,07 and the control treatment has an FCR value of 3.06.
A low FCR level indicated that the efficiency of used feed, because more efficiently livestock consume feed to produce meat [17].

P4 treatment feed showed the greatest FCR level. Mash form feeding influenced on body weight gain could increase the FCR level [15]. The FCR level was influenced by the feeds used, the breeds, and diseases management [3]. The crude fiber content of alfalfa in P3 and $\mathrm{P} 4$ treatments increased duck consumption. This caused by the ability of duck caeca that could only absorb $20 \%$ of crude fiber, the rest would be removed from the digestive tract so that absorption of the feed decreased and the digestive tract became empty. digestive tract emptiness could cause the consumption of ducks increased and affect the FCR [20]. The higher level of protein and energy in the ration will increased feed efficiency because it reduced the level of feed consumption. Conversely, if the low protein content and ratio energy increased in feed consumption so the FCR level would rises [18]. This was evidenced by the value of feed energy in the P1 treatment was $3000 \mathrm{Kcal} / \mathrm{kg}$ and the protein reached $21.90 \%$ so that it got a lower FCR lever, whereas the P4 treatment had a high FCR level because it had the lowest energy and protein level compared to the other treatments (Table 1).

\section{Conclusion}

Based on the results of the study it can be concluded that the feeding treatment to get optimum value of feed consumption, growth in body weight and the value of feed conversion ratio were the treatment with commercial feed without alfalfa supplementation.

The research financial support from Universitas Gadjah Mada on Rekognisi Tugas Akhir (RTA) Program is gratefully acknowledged. The Authors contribution are as follow: Salnan Irba Novaela Samur, Bambang Suwignyo and Edi Suryanto. None of the authors have any conflicts of interest to declare

\section{References}

1. Cultivation Technology in the Field of Law. West Sumatra Agricultural Research and Development (2011)

2. Harsojo, L. Andini, Early bacterial contamination and pathogenic bacterial decontamination in duck meat (Anas javanica) with gamma irradiation. Minutes of Scientific Seminar: Application of Isotopes and Radiation (2006).

3. M.A. Ensminger, Poultry Science (Animal Agricultural Series). 3rd edition. Instate Publisher, Inc. Danville, Illiones (1992).

4. S. Sen, H.P.S. Makkar, K. Becke, J. Agric. Food Chem., 46:131-140 (1998).

5. P.I. Ponte, et al., Poult. Sci., 83:810-814 (2004)

6. National Research Council. Nutrient Requirements of Poultry, Ninth Revised ed. National Academy Press, Washington, DC, USA. (1994).

7. K. Ouyang, M. Xu, Y. Jiang, W. Wang. Can. J. Anim. Sci., 93:331-340 (2016). 
8. Y.J. Zhu, Y. Zhang, Z.L. Ning, R. Wang, X.H. Li, J.Z. Zhao, Acta Nutrimenta Sinica. 30:615-618 (2008).

9. R. Sutrisna, Journal of Applied Agriculture Research. 11,3:1121-1118 (2011).

10. R.G.D. Steel, J.H. Torrie, Statistics Principles and Procedures. PT Gramedia Pustaka Utama. Jakarta (1993)

11. L.M. Potter, J.R. Shelton, British Poultry Science., 14:251-256 (1973).

12. A. Golian, D.V. Maurice, Poultry Science, 70: 45 (1991).

13. M. Purba, A.P. Simurat. Jurnal Ilmu Ternak dan Veteriner, 22,1:1-8 (2017)

14. P.A. Permana, V.D. Yunianto U. Atmomarsono. Animal Agricultural Journal. 3,2:113-120 (2014)

15. Ismoyowati, J. Sumarmono, Asian Journal of Poultry Science. 5,4:150-154(2011).

16. J.F. Jiang, X.M. Song, X. Huang, J.L. Wu, W.D. Zhou, H.C. Zheng, Y.Q. Jiang. British Poultry Science, 53,5:681-688 (2012).

17. H. Allama, O. Sofyan, E. Widodo and HS Prayogi. 2012. J. Animal Sciences. 22 (3): 1-8.

18. W.P.S. Suprayogi, S. Sudibyo, E.H. Susiolo, Journal of Sustainable Agriculture, 32,1:35-41 (2017).

19. P.P. Ketaren, L.H. Prasetyo, JITV 7,2:76-83 (2002).

20. B. Suwignyo, H. Sasongko, IOP Conf. Series: Earth \& Envr. Sci. 387:1-4 (2019).

21. B. Suwignyo, F. Izzati, A. Astuti, E.A. Rini, IOP Conf. Series: Earth \& Envr. Sci., 465:1-6 (2020).

22. Y.F.J. Nuningtyas, Ternak Tropika. 15,1:21-30 (2014). 